\title{
Potential of the physical and chemical characteristics of prickly pear (Opuntia albicarpa Seheinvar var. Villanueva) seeds in agroindustrial processes
}

\author{
Álvarez-Castillo, Mónica de Jesús ${ }^{1}$; Rössel Kipping, Erich Dietmar ${ }^{{ }^{*}}$; \\ López-Martínez, Laura Araceli ${ }^{2}$; Ortiz-Laurel, Hipolito ${ }^{3}$; Amante-Orozco, Alejandro ${ }^{1}$ \\ 1 Colegio de Postgraduados. Iturbide 73, Salinas de Hgo, S.L.P. 78600. México. \\ 2 Universidad Autónoma de San Luis Potosí. Coordinación Académica Región Altiplano Oeste. Carretera \\ Salinas-Santo Domingo 200, Salinas de Hgo, S.L.P. 78600. México. \\ 3 Colegio de Postgraduados. km. 348, Carr. Fed. Córdoba-Veracruz, Congregación Manuel León, Amatlán \\ de los Reyes, Veracruz. 94946. México. \\ * Correspondence: edietmar@colpos.mx
}

Citation: Álvarez-Castillo, M. de J., Rössel Kipping, E. D., López-Martínez, L. A. Ortiz-Laurel, H. \& AmanteOrozco, A. (2021). Potential of the physical and chemical characteristics of prickly pear (Opuntia albicarpa Seheinvar var. Villanueva) seeds in agroindustrial processes. Agro Productividad. https://doi.org/ 10.32854/agrop.vl4i10.1834

Editor in Chief: Dr. Jorge Cadena Iñiguez

Received: February 21, 2021. Accepted: September 14, 2021.

Published on-line: November 8, 2021

This work is licensed under a Creative Commons Attribution-NonCommercial 4.0 International license.

\section{ABSTRACT}

Objective: To verify the physical attributes and assess the chemical quality from prickly pear's seeds $($ Opuntia albicarpa Seheinvar cv. Villanueva), including seeds' size, internal friction, external friction, performance for size reduction, sieving and electric conductivity, soluble protein, total protein, phosphorous, carbohydrates, amount of oil and minerals.

Design/methodology/approach: To verify and compare the physical attributes and chemical parameters using proved and reliable techniques, to explore their impacts on its future potential, when seeds are intended to agro-industrial processes, considering; its size and quality of space storage and their effect when interacting with handling apparatus and the material they are manufactured with.

Results: Selected groups of 100 seeds from four consecutive prickly pears harvests had no differences. While for their chemical analysis, seeds were milled and their revised chemical compounds showed differences between harvest, therefore, drought, management and crop protection significantly affect those attributes. The factors were not included in this study.

Limitations on study/implications: Prickly pears are harvested for 4 months per year. This reduces the availability of raw material from other varieties and from other regions, to expand this study and to compare between diverse parameters.

Findings/conclusions: There were not significant differences in seed size (wide, large, thickness), external friction and electric conductivity; therefore, handling equipment does not need specifications. While, for the internal friction and all chemical compounds analyzed from seeds' flour, significate differences were quantified. The latter means that, it is adequate to homogenize these parameters by using other compounds in the agrifood processes.

Keywords: agroindustry, technological processes, chemical compounds, physical attributes, seeds from cactus prickly pear. 


\section{INTRODUCTION}

Arid and semi-arid zones comprise about half the Mexican surface. Within it there are grasslands and isolated tree vegetation (Rzedowski, 1988). The main present plant resources include mesquite, candelilla, maguey, jojoba, "vegetable" nopal, "forage" nopal and "tunero" nopal. From them, various products such as fibers, syrups, fermented beverages, and soaps are obtained and prepared (Cervantes-Ramírez, 2005). In the case of the nopal (Opuntia spp.), by processing its fruit (prickly pear), honey, cheeses, jellies, jams, wines, shampoos, soaps, creams, colorants, organic acids, construction materials and filters, among others are produced. There is, therefore, high industrial demand for this raw material availability (Mohsenin Nuri, 1986). Therefore, it is a priority that the agro-industrial transformation processes (processing technologies) become increasingly efficient. Due to the above, it is convenient to introduce the concept of Industry 4.0 (Pat Mooney, Grupo ETC 2018), which consists of the digitization of production processes to obtain indicators, with the help of sensors and information systems. Although, it is important to note that the interaction of technical tools with biological material is still incipient, so its digitization represents great challenges. The advancement of new technologies in the industry, in which the digital part is merged with industrial processes (Industry 4.0), today is a necessity to develop technically produced products. Associated with the fact that agribusiness evolves according to the food needs, energy, water, and biomaterials, without neglecting to minimize the environmental impact. A significant advance comes from using raw material by-products, for example, for prickly pear case, using its seeds in industrial processes. Prickly pears contain numerous seeds in their pulp, which are not used and discarded by producers, even though extracting oil from them is feasible. For their industrialization, it's convenient to characterize these inputs potential, from both a physical and chemical perspective, to guarantee adequate and technologically correct processes. For prickly pear seeds, there are no records that involve mechanized industrial uses, for example, that involve the development of machines for harvesting and storing them, especially for the transformation and elaboration of agroindustrial products. The SIAP (2004) indicates that in México, the prickly pear nopal occupies sixth place in fruit production, behind oranges, avocado, bananas, mangos, and apples.

In Mexico, there are about 53,000 hectares of nopal orchards that annually produce 344,000 tons of prickly pear. According to Martínez et al. (2010), one of the main problems for nopal producers is the harvest seasonality. The prickly pear is harvested for 90 days, therefore, when the production is high; $60 \%$ of the harvest is lost. Sumaya-Martínez et al. (2010) detail that it is mainly due to deficiencies in the commercialization, such as: a) lack of an assured market, b) lack of adequate storage and storage spaces for the conservation of the prickly pears, c) lack of transportation infrastructure to mobilize the product and d) disarticulation of the production chain where the production and marketing processes are taken separately. Using the seeds from the losses contributes to reduce and solves some problems, that is why the seeds are a current research object.

Inside the peel and pulp, there is an average of 91 to 388 seeds, with a size between $2.16 \mathrm{~mm}$ to $4.34 \mathrm{~mm}$. The prickly pears have a high nutritional value, it is an accessible 
product to industrialize; Its characteristics allow them to be used as biomaterials (colorants), although to increase the processes effectiveness, it is necessary to apply better technologies and offer an adequate post-harvest treatment, as well as seek storage options, such as productive processing of both prickly pears and its seeds.

Agribusiness and the food processing industry intend to ensure that products have high nutritional value and pleasant sensory characteristics for the consumers. Therefore, technologies must be used, with which to participate in the fourth industrial revolution or intelligent industry, which promotes the total integration of information and knowledge in all stages of a product life cycle in an automated way, in this case, achieving the interaction of the technical tools with the organic materials. To industrialize the processes, knowledge of the materials is necessary, hence the importance of characterizing them both physically and chemically.

The physical and chemical characteristics of prickly pear seeds represent a guide for its potential to get sustainable processing, in which, these physical parameters do not destroy any chemical or biological characteristics of the product and thus guarantee high-quality products and many of them during their processing.

\section{MATERIALS AND METHODS}

In this research, prickly pear seeds form the Opuntia albicarpa Seheinvar cv. Villanueva were used, corresponding to different harvests from the municipality of Villanueva, Zacatecas (22 $21^{\prime} 13^{\prime \prime} \mathrm{N}, 102^{\circ} 52^{\prime}$ 59” W). The research was carried out at Salinas de Hidalgo, San Luis Potosí at the San Luis Potosí Campus of the Colegio de Postgraduados and the Western Altiplano Region Academic Coordination of the San Luis Potosí Autonomous University.

Physical and chemical parameters were analyzed due to the importance of the active contact of the organic material with the engineering tools in agro-industrial processes: a) physical characteristics including 1) size (length, width and thickness), 2) internal and external friction, 3) grinding (particle size), 4) electrical conductivity, 5) screening and b) chemical characteristics including 1) humidity 2) carbohydrates, 3) total proteins, 4) lipids, 5) soluble proteins and 6) phosphorus.

\section{RESULTS AND DISCUSSION}

At random, 100 seeds of the O. albicarpa Seheinvar cv. Villanueva were collected from four crops. The measurement of each seed's width, length and thickness were made with a digital vernier showing an LCD display and digital calibration (0.001 $\mathrm{mm}$ precision). The statistical analysis indicates that none of the fruit harvestings had a significant effect on the cv. Villanueva seeds dimensions; therefore, the width, length and thickness were not statistically different among the four harvests $(\mathrm{p}>0.05)$. Table 1 shows the indicators of the values of the three measurements, which allow the selection of technical parameters; for example, the sizes of the holes in the screens or the shape of the slits that the presses used for obtaining oil must have, to be sure of achieving the highest efficiency in agro-industrial processes. 
Table 1. Average data of the sizes of prickly pear seeds.

\begin{tabular}{l|c|c|c}
\hline \multirow{2}{*}{\multicolumn{1}{c|}{ Parameter }} & Wide & Length & Thickness \\
\cline { 2 - 4 } & \multicolumn{3}{|c}{$(\mathbf{m m})$} \\
\hline Average & 3.58 & 4.23 & 2.00 \\
\hline Variance & 0.17 & 0.21 & 0.11 \\
\hline Standard deviation & 0.41 & 0.46 & 0.33 \\
\hline
\end{tabular}

In the case of the measurement of the internal friction of the $\mu_{i}$ seeds, the method described in Figure 1 was used. The statistically processed data of the internal friction $\left(\mu_{i}\right)$ of the different crops with a $\mathrm{p}<0.0001$, were determined via the Tukey's test (Table 2).

The determination of the angle results from the value of the height $(\mathrm{h})$ divided by $1 / 2$ of the diameter $(\mathrm{d})$ of the pile of organic material, it results that $\tan \beta=h / r$ and $\tan \beta=\mu_{i}$.

The values of the internal friction allow selecting, with sufficient technical security, the angle of the cone for the exit of material from a vertical silo (Figure 2). When physical data is applied, it guarantees a continuous flow of the grain material inside the storage container. This means that the material entering the container comes out in the same order it came into the silo, there is no mixing, there are no different storage times and there are no chemical changes in the contents. Hence, the material as a component of a diet is clearly defined and can be planned according to the content of its nutritional values.

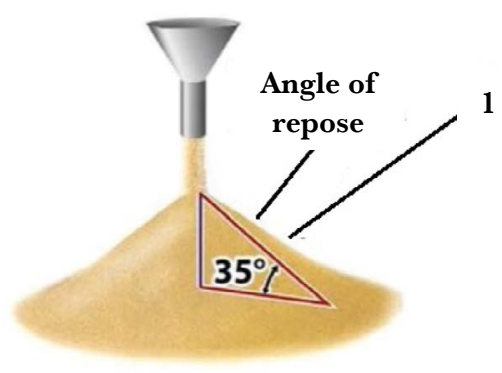

Fine sand

Figure 1. Measurement of internal friction (viscosity of the granular material). Where: 1 Cone of the granular material; $\beta=$ angle of repose.

Table 2. Internal friction $\mu_{i}$ from Villanueva's seeds for four different fruit harvests.

\begin{tabular}{c|c|c}
\hline$/-\mu_{i}$ & $\pm \sigma \mu_{i}$ & $\begin{array}{c}\text { Villanueva variety Fruit } \\
\text { (harvest) }\end{array}$ \\
\hline 0.194 & 0.017 & $1(2013) \mathrm{a}$ \\
\hline 0.216 & 0.025 & $2(2014) \mathrm{a}$ \\
\hline 0.141 & 0.033 & $3(2015) \mathrm{b}$ \\
\hline 0.215 & 0.042 & $4(2016) \mathrm{a}$ \\
\hline
\end{tabular}

Letters a,b, indicate that there is statistical difference between fruit harvest. 


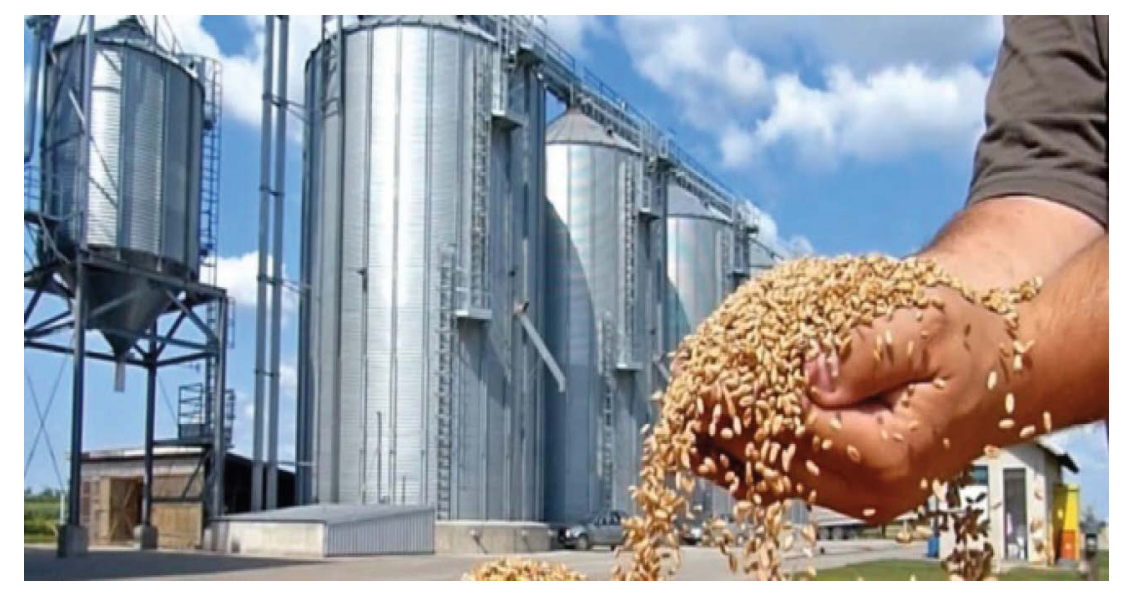

Figure 2. Array of large vertical steel silos for grain storage.

Regard the measurement of external friction $\left(\boldsymbol{\mu}_{e}\right)$, it presented significant differences during movement due to the gravity of the seeds, which is a function of the different materials on which it made contact, with a $p<0.05$ determined with the Tukey's test. The external friction measurement values $\left(\boldsymbol{\mu}_{e}\right)$ are shown in Table 3 . These values are the result of the measurement process with the physical phenomenon of the following equation:

$$
F_{r}=\mu_{e} * F_{n}
$$

Where: $F_{r}$ - friction force; $F_{n}$ - normal force; $\mu_{e}$ coefficient of friction between the organic material (not ideal elastic) and the material of a conveyor belt or plate made of a solid material and with an angle of inclination in relation to the horizontal plane (Figure 3).

For the case of requiring its transportation in the horizontal direction of grains, for example, from a warehouse to a dispenser or mixer due to gravity force, the passive conveyor needs at least one inclination angle, which must result in the type of organic material and the material of the technical conveyor on which said material is placed. This form of

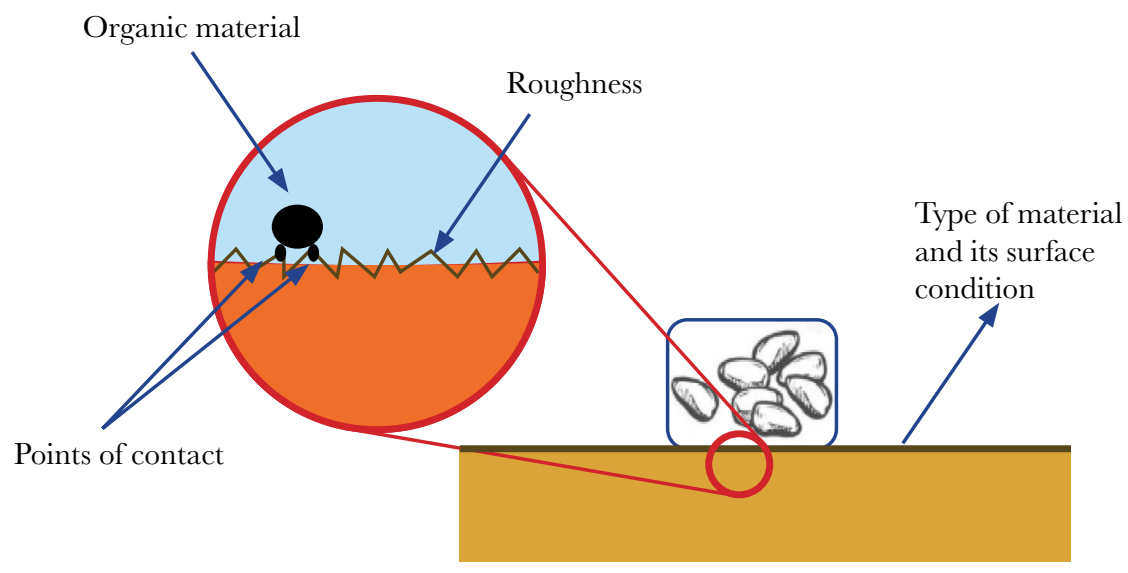

Figure 3. Contact of organic material with a solid surface 
transport is a possibility to save technical energy for the process, which can guarantee a continuous technological flow.

The variation of the average values and their respective standard deviation has a very narrow range, which allows the manufacture of technical installations with a high degree of safety without difficulties. Table 3 shows the average friction values of seed flour of the different cv. Villanueva prickly pears harvests obtained during their movement on different materials. If a selection of material is required to manufacture a gravity conveyor, the most convenient angle of inclination is the one with the lowest value, in this case, the glass would be ideal, also the height of the space for a conveyor is smaller compared to that of other materials. The standard deviation values allow confidence in selecting the correct contact material for a conveyor. The friction forces against the movement of flour on a conveyor with a surface made of glass would have a minimum value. Although sometimes, it is convenient to consider other factors such as its price, e. g. wood is cheaper and with proper maintenance, its useful life may be lengthened; in addition to being a degradable good, it contributes to environmental preservation. The parameters for flour (Table 3) are high, which is due to its technical processing, while the values of the seeds in Table 3 are lower, largely due to its more natural character.

Figure 4 shows the variation of the external friction values of the seeds and the flour obtained from grinding seeds when both products are being handled through different materials, in which it is observed that they both lack the representativeness of the normal distribution. This situation is characteristic of physical values, which result from a certain process, based on an unnatural parameter, but achieved in a technical or artificial installation. Regard the seed's size reduction, the process was complicated, due to the thick pericarp that surrounds the embryo, for which two processes were done; first, the pericarp of the seeds was broken in a mortar and subsequently cut into small particles in a coffee bean mill (using the free cutting principle), turning it into a coarse flour.

Table 4 shows that the sieve in which the largest amount of flour accumulates was 419 $\mu \mathrm{m}$. This result is important since, even when it is complicated to reduce the size of the prickly pear seed particles, giving it the appropriate processing, it is possible to manipulate them in other processes to generate industrial products. Some authors have classified the flours of other products (e.g. coffee) according to their average diameter, and mention that the size of the particles has a marked influence on the final product's characteristics

Table 3. External friction $(\mu \mathrm{e})$ of the seed and flour of $\mathrm{cv}$. Villanueva prickly pear seeds for the 3rd $(\mathrm{n}=300)$ and 4 th $(\mathrm{n}=400)$ harvests.

\begin{tabular}{c|l|c|c|c|c}
\hline $\begin{array}{c}\text { Sample size } \\
(\mathbf{n})\end{array}$ & Material & $\begin{array}{c}\text { Average } \\
\left(\mu_{\mathbf{e}}\right) /-/ \text { flour }\end{array}$ & $\begin{array}{c}\text { Standard deviation } \\
\left(\mu_{\mathbf{e}}\right) /-/ \text { flour }\end{array}$ & $\begin{array}{c}\text { Average } \\
\left(\mu_{\mathbf{e}}\right) /-/ \text { grain }\end{array}$ & $\begin{array}{c}\text { Standard deviation } \\
\left(\mu_{\boldsymbol{e}}\right) /-/ \text { grain }\end{array}$ \\
\hline 300 & Plastic & 0.93 & 0.02 & 0.662 & 0.035 \\
\hline 400 & Geramic & 0.84 & 0.03 & 0.425 & 0.012 \\
\hline 400 & Rough wood & 0.93 & 0.05 & 0.861 & 0.063 \\
\hline 400 & Wood & 0.98 & 0.04 & 0.613 & 0.061 \\
\hline 400 & Steel & 0.76 & 0.04 & 0.433 & 0.019 \\
\hline 300 & Glass & 0.64 & 0.02 & 0.384 & 0.015 \\
\hline
\end{tabular}




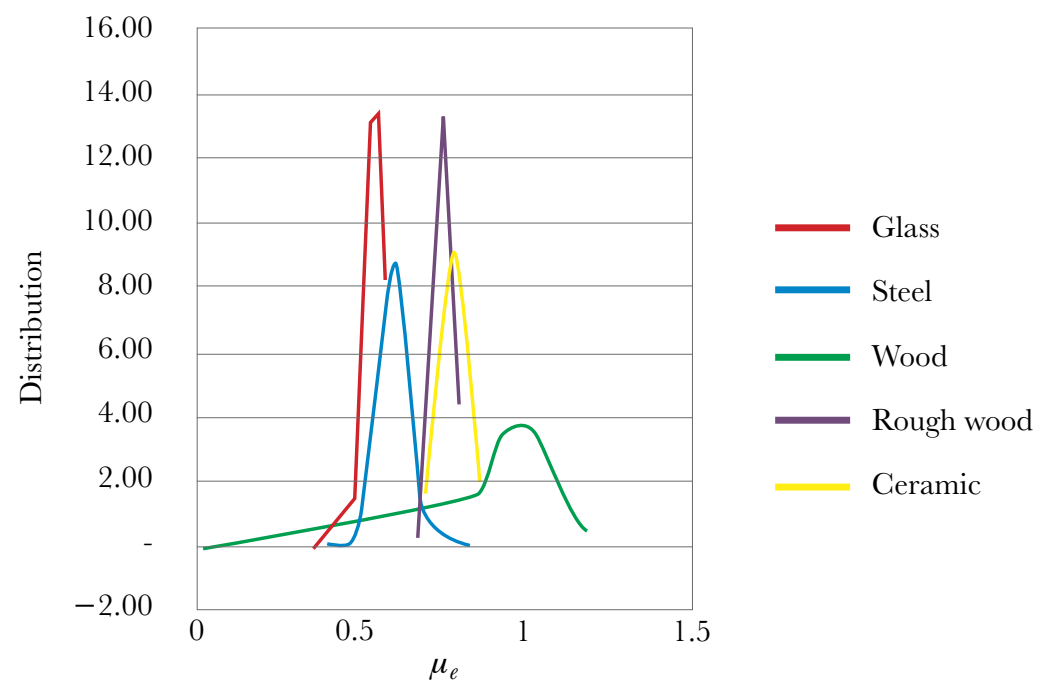

Figure 4. External friction of the flour of the prickly pear seeds.

Table 4. Prickly pear seeds flour particle sizes.

\begin{tabular}{c|c|c|c|c}
$\begin{array}{c}\text { Sieve } \\
(\mathbf{m})\end{array}$ & $\begin{array}{c}\text { Flour of seeds from } \\
\text { fruit harvest } \mathbf{1}(\mathbf{g})\end{array}$ & $\begin{array}{c}\text { Flour of seeds from } \\
\text { fruit harvest 2 }(\mathbf{g})\end{array}$ & $\begin{array}{c}\text { Flour of seeds from } \\
\text { fruit harvest 3 }(\mathbf{g})\end{array}$ & $\begin{array}{c}\text { Flour of seeds from } \\
\text { fruit harvest 4 }(\mathbf{g})\end{array}$ \\
\hline 1999 & 10.52 & 11.561 & 16.68 & 14.94 \\
\hline 1409 & 37.74 & 42.35 & 51.99 & 44.72 \\
\hline 419 & 136.27 & 158.41 & 154.66 & 149.71 \\
\hline 131 & 44.57 & 61.79 & 54.62 & 75.36 \\
\hline 73 & 7.58 & 13.43 & 7.12 & 2.08 \\
\hline
\end{tabular}

(Guevara and Cataño, 2005). As previously reviewed, the highest percentage of flour (50-60\%) was retained on the $419 \mu \mathrm{m}$ sieve, as it was ground in a coffee mill without any previous heat treatment (Table 4), and is considered as that generated in a fine grind. The second sieve in which flour was retained was the $131 \mu \mathrm{m}$ sieve. The 1986 National Technical Standard (ITINTEC .205-027) establishes that fortified wheat flour must pass at least $98 \%$ through a 212 -micron sieve.

To achieve a suitable mixture with different flours it is important to consider their physical characteristics, such as the size and shape of the particles (Table 4 and Figure 5), substance density, as well as its chemical characteristics, such as humidity, content, and quality of oils, among others. Likewise, it is necessary to assess the affinity with other components of the mixture. For example, once cornflour has been selected, to determine it choosing by affinity degree, the two parts of the mixture are mixed and thus determine its affinity by its grinding degree.

Regarding the electrical conductivity of the seeds, the agro-food industry uses different processes to generate inputs to produce market products such as pastries, "tortillas" or balanced forage for animals. The processing of these products is, in most cases, linked to thermal, hydraulic (solubility), mechanical, optical and chemical phenomena. Electrical conductivity is a general evaluation that involves these parameters since there 

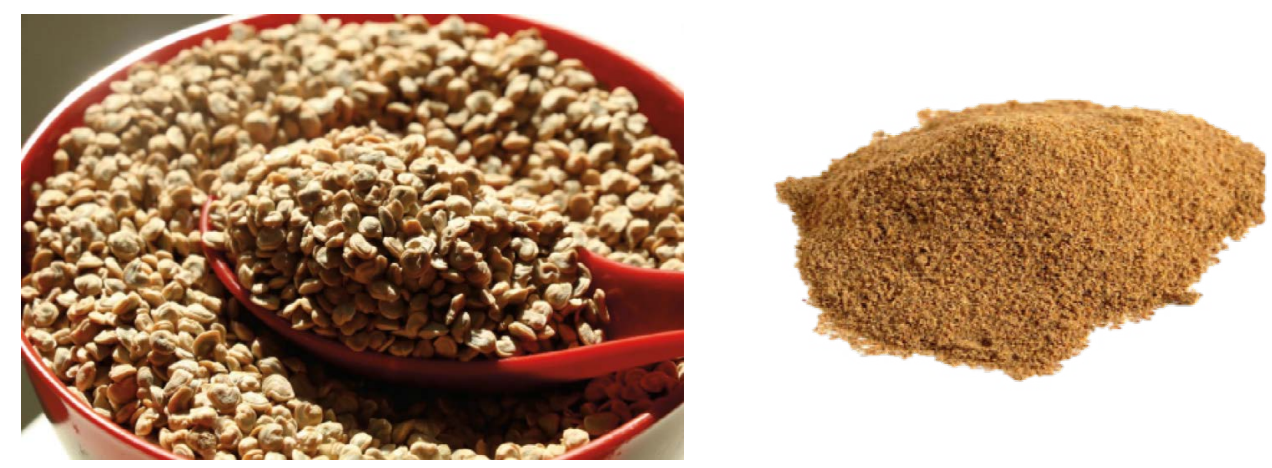

Figure 5. Image of prickly pear seeds (left) and their flour (right).

is a determined physically relationship between electrical conductivity values and the mentioned parameters (Table 5).

The results are useful in the biomaterials industry, where the seed can be used as a thermal insulator, in controlling the temperatures of the processes, such as in the piglet beds or the artificial nests of the "escamoles" (ant egg).

To determine the moisture content of the prickly pear seed samples, the AOAC Method was used. 925.10. The protein determination of the flours was carried out based on the Standard (NMX-F-068-S, 1980) following the Kjeldahl method and the soluble protein quantification analyzes were carried out by the Lowry method. The analysis for the quantification of oil was carried out using the Soxhlet technique following the NMX-F-089-1978 Standard. The determination of the carbohydrate content of the prickly pear seeds was carried out based on the NMX-F-312, 1978 Standard. Finally, for the phosphorus analysis, the samples were digested in microwave equipment and their analysis was performed via UV spectrophotometry, based on the NOM-AA-29-1981 Standard.

The use of flours from previously unexplored food sources, or in combination with other commercial flours for the generation of new products can contribute to increase the nutritional value of the products or improve its technological characteristics. However, for flours elaboration, as well as to elaborate the products derived from them, it is important to consider the equipment characteristics and the processes that will be used on them.

Hence the importance of applying technology to preserve the quality of the final product for its nutritional content, in addition to the fact that it must be attractive to the consumers, promoting its sale. This entails the design of machinery and the application of the appropriate processes, both in the production of flour and in that of food products,

Table 5. Values of electrical conductivity from prickly pear seeds flour.

\begin{tabular}{c|c}
\hline Flour from prickly pear var. Villanueva (year) & Electric conductivity $(\mathbf{m s} / \mathbf{m})$ \\
\hline Fruit harvest 1 a & $0.240 \pm 0.050$ \\
\hline Fruit harvest 2 a & $0.293 \pm 0.088$ \\
\hline Fruit harvest 3 a & $0.270 \pm 0.050$ \\
\hline Fruit harvest 4 a & $0.285 \pm 0.002$ \\
\hline
\end{tabular}

Letter a indicates that there is not statistical difference between crop harvests. 
so that, in addition to knowing their physical qualities, the behavior of the chemical characteristics must be understood (Table 6).

There is no doubt that it is feasible to carry out adequate technological processes to avoid nutrients loss from the organic material during their process when there is an understanding of the meaning of the parameters measured in this investigation. Thus, the moisture content of the seeds was between $4 \%$ and $6.5 \%$, like that reported by other authors in other fruit seeds (Monroyetal, 2017). The main advantages of a reduced moisture content food are that it tends to have less water activity and these influences reduce physical, chemical, enzymatic and microbiological reactions, related to food spoilage, as well as those that may arise from the interaction with the materials, they are in contact with from which the equipment is made. Regarding the carbohydrate content in prickly pear seeds, values between $7.54 \%$ and $19.72 \%$ were found, which differed significantly depending on the year of cultivation $(p=0.0001)$. In the year 2013 , the carbohydrate content was higher, while the 2014 and 2015 crop years had the lowest percentages with $7.54 \%$ and $8.07 \%$ respectively (Table 6 ).

Currently, many diets have a high carbohydrate content, so that the energy provided by them is consumed in greater proportion than required by the same diets causing health problems, such as obesity, which can lead to diabetes or other diseases (Piernas and Popkin, 2010). This particular flour has low carbohydrate content and acceptable fiber content, compared with other flours in the market therefore its consumption can be associated with health benefits. As for the total protein, lipid and phosphorus content in the samples analyzed, the values obtained revealed that these nutrients showed significant differences between these years $(p=0.0001)$. All the differences between nutrients in the different crop years may be due to the prevailing climatic conditions, the presence of pests and diseases, the period of fruit development and the time the seeds were stored.

This should be verified to ensure that the product market has the same qualities and the same nutritional value. Likewise, it was found that the protein, lipid and phosphorus values of these flours are similar to those of commercial wheat flours. Therefore, when developing equipment for processing prickly pear seed flour and/or mixtures with other flours, as well as for product development, the process temperatures should be considered to avoid color changes in the products because of the darkening reactions due to carbohydrate and protein content, aggregation or denaturation of proteins and nutritional loss (Carbonaro $e t$ al., 1997).

Table 6. Selected chemical characteristics for agro-industrial processes.

\begin{tabular}{c|c|c|c|c|c|c}
\hline $\begin{array}{c}\text { Fruit harvest } \\
(\text { year})\end{array}$ & $\begin{array}{c}\text { Carbohydrates } \\
(\%)\end{array}$ & $\begin{array}{c}\text { Total protein } \\
(\%)\end{array}$ & $\begin{array}{c}\text { Lipids } \\
(\%)\end{array}$ & $\begin{array}{c}\text { Moisture } \\
\text { content }(\%)\end{array}$ & $\begin{array}{c}\text { Soluble protein } \\
(\%)\end{array}$ & $\begin{array}{c}\text { Phosphorous } \\
(\%)\end{array}$ \\
\hline 1 & $19.72 \pm 0 \mathrm{a}$ & $7.20 \pm 0.14 \mathrm{~b}$ & $11.0 \pm 4.2 \mathrm{a}$ & $4.94 \pm 0.14 \mathrm{~b}$ & $0.38 \pm 0 \mathrm{a}$ & $0.93 \pm 0 \mathrm{a}$ \\
\hline 2 & $7.54 \pm 0.09 \mathrm{~d}$ & $4.99 \pm 0.13 \mathrm{~d}$ & $5.5 \pm 0.7 \mathrm{~b}$ & $4.9 \pm 0.05 \mathrm{~b}$ & $0.29 \pm 0 \mathrm{c}$ & $0.82 \pm 0 \mathrm{e}$ \\
\hline 3 & $8.07 \pm 0 \mathrm{~d}$ & $7.64 \pm 0.04 \mathrm{a}$ & $5.0 \pm 0 \mathrm{~b}$ & $5.09 \pm 0.03 \mathrm{a}$ & $0.34 \pm 0 \mathrm{~b}$ & $0.87 \pm 0 \mathrm{~b}$ \\
\hline 4 & $11.42 \pm 0.11 \mathrm{c}$ & $7.10 \pm 0.03 \mathrm{~b}$ & $3.0 \pm 0 \mathrm{~b}$ & $4.81 \pm 0.21 \mathrm{~b}$ & $0.25 \pm 0.01 \mathrm{c}$ & $0.84 \pm 0 \mathrm{c}$ \\
\hline
\end{tabular}

The letters a, b, c, d, indicate there is a statistical difference between the materials. 
The physical properties are largely influenced by the chemical values, most probably the internal friction values show different behavior in the different harvest years due to the difference in humidity and fat that they present in those years. The internal friction of the material is also influenced by the biomolecules that constitute it. While regarding particle size reduction for flour production, it is also necessary to take into account both moisture and fat content, as these figures should be much less as those for the optimum particle size that was used in this research, as their actual data cause oil syneresis, resulting in caking of the flour.

\section{CONGLUSIONS}

The data registered on the physical characteristics of prickly pear seeds allow guaranteeing an integral interaction between the biological material with the equipment materials that will be used to process them agroindustrially, whose purpose is to obtain maximum efficiency of the process with a minimum of losses. Also, the content of chemical components in prickly pear seed flours contributes to increasing the nutritional and/or technological value when mixed in the appropriate proportions with other grain and cereal flours. Regarding the qualities of prickly pear seed flour, since it lacks odor and has high fiber content, it can be used as a thickening agent and cause a pasty texture in consumer products. In addition, due to the content of biomolecules contained in this product, the possibilities of complications during the interaction with the equipment material used in the agroindustrial treatment, as well as in the process during the elaboration of the final products, are reduced.

\section{REFERENGES}

Carbonaro, M., Cappelloni, M., Nicoli, S., Lucarini, M., Carnovale, E. (1997). Solubility-digestibility relationship of legume proteins. Journal of Agricultural and Food Chemistry, 45, 3387-3394.

Cervantes-Ramírez, M. (2005). Plantas de importancia económica en zonas áridas y semiáridas de México. Anais do X encontro de Geógrafos de América Latina. Brasil: Universidad de Sao Pablo. Colegio de Geografía. Facultad de Filosofía y Letras UNAM, México. 3388-3407.

Martínez, S., Suarez, D., Cruz, C, García, A. (2010). Innovación de productos de alto valor agregado a partir de la tuna mexicana. Revista mexicana de agronegocios. 27. 435-441

Monroy, V.E., Peña, V.B., García, N. R., Solano, C. E., Huitziméngari, C., García, V. E. (2017). Imbibición, viabilidad y vigor de semillas de cuatro especies de opuntia con grado distinto de domesticación. Agrociencia 51, (1). 27-42.

Piernas, C., Popkin, B.M. (2010). Snacking Increased among U.S. Adults between 1977 and 2006. The Journal of nutrition, 140 (2): 325-332. Doi: 10.3945/jn.109.112763

Rzedowski, J. (1988). Análisis de la distribución geográfica del Complejo Prosopis en Norteamérica. Acta botánica Mexicana, 3: 7-19.

SIAP. (2004). Servicio de información y Estadística Agroalimentaria y Pesquera. Avance de Siembras y Cosechas Perennes 2004. Disponible en http://www.sagarpa.gob.mx/sagar5htm 